\title{
Invasion by Invitation: Rhizobial Infection in Legumes
}

\author{
Jeremy D. Murray \\ John Innes Centre, Norwich Research Park, Colney, Norwich, NR4 7UH, U.K. \\ Submitted 5 August 2010. Accepted 26 January 2011.
}

\begin{abstract}
Nodulation of legume roots typically begins with rhizobia attaching to the tip of a growing root-hair cell. The attached rhizobia secrete Nod factors (NF), which are perceived by the plant. This initiates a series of preinfection events that include cytoskeletal rearrangements, curling at the root-hair tip, and formation of radially aligned cytoplasmic bridges called preinfection threads (PIT) in outer cortical cells. Within the root-hair curl, an infection pocket filled with bacteria forms, from which originates a tubular invagination of cell wall and membrane called an infection thread (IT). IT formation is coordinated with nodule development in the underlying root cortex tissues. The IT extends from the infection pocket down through the root hair and into the root cortex, where it passes through PIT and eventually reaches the nascent nodule. As the IT grows, it is colonized by rhizobia that are eventually released into cells within the nodule, where they fix nitrogen. NF can also induce cortical root hairs that appear to originate from PIT and can become infected like normal root hairs. Several genes involved in NF signaling and some of the downstream transcription factors required for infection have been characterized. More recently, several genes with direct roles in infection have been identified, some with roles in actin rearrangement and others with possible roles in protein turnover and secretion. This article provides an overview of the infection process, including the roles of NF signaling, actin, and calcium and the influence of the hormones ethylene and cytokinin.
\end{abstract}

Rhizobia and legumes establish a mutualistic symbiosis, which leads to the morphogenesis of nodules where rhizobia eventually locate and fix $\mathrm{N}_{2}$. The establishment of this symbiosis requires the successful infection of legume roots, which is a multifaceted developmental process that is driven by the bacteria but is ultimately under the control of the host. These events are reviewed in great detail in (Gage 2004) and more recently by Oldroyd and Downie (2008) and Kouchi and associates (2010), and a thorough look at infection from the microbial perspective has been provided by Downie (2010) and Jones and associates (2007). The following discussion is concerned with host factors required for infection prior to symbiosome formation and the roles of cytokinin and ethylene in infection thread (IT) formation. Recent genetic progress in the area of IT formation and progression and its relationship to the components of Nod factor (NF) signaling will be discussed.

Corresponding author: J. D. Murray; E-mail: jeremy.murray@bbsrc.ac.uk

\section{PRE-ENTRY EVENTS}

NF-signaling.

In the two model legumes Lotus japonicus and Medicago truncatula, rhizobial infection normally starts with attachment of the bacteria to the tips of growing root hairs and is followed by formation of a characteristic "shepherd's crook" curl structure at the root-hair tip, within which a bacterial microcolony is established, forming a so-called infection pocket. At this point, the root hair ceases its outward growth and begins to grow inward, forming a tubular IT, in which bacteria reproduce behind the growing tip (Fournier et al. 2008). Eventually, the IT extends though the epidermis and into the growing nodule, where bacteria are taken up into cells and begin to fix $\mathrm{N}_{2}$. Thus, the programs of IT development and the cortical programs of nodule organogenesis are coordinated (Guinel and Geil 2002; Oldroyd and Downie 2008). The programs of infection and nodule development are induced by the lipochitooligosaccharides secreted by rhizobia called Nod factors (NF). This signal is perceived by the plant epidermal cells by the Nod factor receptors NOD FACTOR RECEPTOR 1/LYSM DOMAIN CONTAINING RECEPTOR-LIKE KINASE 3 (NFR1/LYK3) and NFR5/NOD FACTOR PERCEPTION (NFP), where it enables infection and is concomitantly relayed to the subtended cortical cells, where it initiates the formation of the nodule (Arrighi et al. 2006; Limpens et al. 2003; Madsen et al. 2003; Radutoiu et al. 2003). Many of the developmental events that occur during nodulation can be induced by NF alone. These preinfection responses ready the root for infection by rhizobia. After exposure of growing root hairs to $\mathrm{NF}$, actin rearrangements happen within 3 to 5 min (Allen et al. 1994; Weerasinghe et al. 2005), nuclear calcium spiking occurs within 15 min (Ehrhardt et al. 1996; Sieberer et al. 2009), and the first root-hair deformations occur within 1 to 3 h (Heidstra et al. 1994; Sieberer et al. 2009). Responses to NF in the inner root tissues are slower; microtubule rearrangements and nuclear activation are evidenced at 16 to $18 \mathrm{~h}$ in pericycle cells and similar events take place in the cortex at 18 to $24 \mathrm{~h}$ (Timmers et al. 1999). This results in the synchronization of primordium formation with the initiation of IT in epidermal cells. None of these events can occur without NFsignaling.

A branch in NF signaling: the common symbiosis and parallel pathways.

A prerequisite to infection and nodulation programs is the activation of signaling pathways by the NF receptors. The induction of nuclear $\mathrm{Ca}^{2+}$ oscillations by NF is one of the earliest responses in the root hairs of legumes. The mutants $n f p / n f r 5$ and $n f r 1$, nucleoporin 85 (nup85), nup133, castor, pollux/does not make infections 1 (dmil), and symbiosis receptor-like kinase 
(symrk)/dmi2 lack the ability to produce NF-induced nuclear $\mathrm{Ca}^{2+}$ oscillations in growing root-hair tips and generally fail to initiate IT and cortical cell divisions (CCD) (Amor et al. 2003; Charpentier et al. 2008; Endre et al. 2002; Imaizumi-Anraku et al. 2005; Kanamori et al. 2006; Madsen et al. 2003; Miwa et al. 2006; Saito et al. 2007; Stracke et al. 2002). In L. japonicus, it was shown that, when the spontaneous nodulation allele of CCaMK (T265I) (spontaneous nodule formation [snfl] allele encoding autoactive $\mathrm{CCaMK}$ or $\mathrm{CCaMK}^{*}$ ) was introduced into these mutants, nodule infection by rhizobia still occurred via epidermal IT (Madsen et al. 2010). This illustrates that the primary purpose of these NF signaling elements in infection is to activate CCaMK, a calcium calmodulin kinase. CCaMK has been suggested to be responsible for interpretation of the $\mathrm{Ca}^{2+}$ signature, indicating a major role for $\mathrm{Ca}^{2+}$ signaling in the formation of NF-induced IT and nodules. CCaMK, NUP85, NUP133, CASTOR, POLLUX/DMI1, and SYMRK/DMI2 are also required for successful interactions with arbuscular mycorrhiza and comprise the so-called common symbiosis pathway (Kistner et al. 2005).

Several transcription factors act downstream of the common symbiosis pathway. Nodulation signaling pathway 1 (nspl), nsp2, ERF required for nodulation 1 (ern1), and nodule inception (nin) can undergo symbiotic root-hair deformations but form infrequent microcolonies and lack epidermal IT and CCD, with some leakiness in ernl and $n s p l$, which form infrequent IT and nodule primordia (Catoira et al. 2000; Hayashi et al. 2010; Heckmann et al. 2006; Kalo et al. 2005; Levy et al. 2004; Middleton et al. 2007; Mitra et al. 2004; Miwa et al. 2006; Murakami et al. 2006; Oldroyd and Long 2003; Smit et al. 2005; Wais et al. 2000; Yano et al. 2008). Microcolonies have been reported on the weak nin-2 allele but not on nin-1 (Hayashi et al. 2010; Marsh et al. 2007). The aborted IT and small nodule primordia on ernl mutants may be a result of genetic redundancy because a second family member, ERN2, is NF inducible and expressed during nodulation, and ERN2 binds to and activates NF box-containing reporters (Andriankaja et al. 2007). Creation of an ern1 ern2 double mutant would provide a clearer picture of the role of these transcription factors. In L. japonicus, the transcription factors $N S P 1, N S P 2$, and NIN were shown to be necessary for formation of IT and CCD in the ccamk* background, showing they act downstream of CCaMK. CYCLOPS/IPD3 interacts with CCaMK (Messinese et al. 2007; Yano et al. 2008). However, cyclops mutants form microcolonies, indicating that they act downstream of $C C a M K, N S P 1, N S P 2$ and NIN during infection (Fig. 1) The cyclops roots transformed with a ccamk* construct produced spontaneous nodules that did not become infected when inoculated with rhizobia, further indicating an important role for CYCLOPS in IT formation (Madsen et al. 2010; Yano et al. 2008).

\section{The parallel pathway.}

Earlier observations that the NF signaling pathway mutants nup85, nup133, dmi1, dmi2, and ccamk exhibit some NF-dependent root-hair responses that are absent in the NF receptor mutants suggested that a parallel signaling pathway required for initiation of infection is operating in concert with the common symbiotic genes downstream of NF perception (Esseling et al. 2004; Kanamori et al. 2006; Miwa et al. 2006; Saito et al. 2007). Recently, it was shown that, when provided with $c c a m k^{*}$, $n f r l$ and $n f r 5$ mutants did not form epidermal IT (Hayashi et al. 2010; Madsen et al. 2010). This shows that, although activation of CCaMK is necessary for bacterial entry, it is not sufficient. Thus, the NF receptors must mediate a CCaMK-independent function that is essential for the formation of IT (Fig. 1). In addition to rhizobial infection, the parallel pathway may also play a role in NF-mediated root-hair development (Oldroyd et al. 2001). It's not yet clear whether the NF-induced root-hair deformation and IT-initiation pathways are mechanistically related; however, pharmacological studies implicate lipid signaling in both processes. Inhibition of phosphatidylinositol

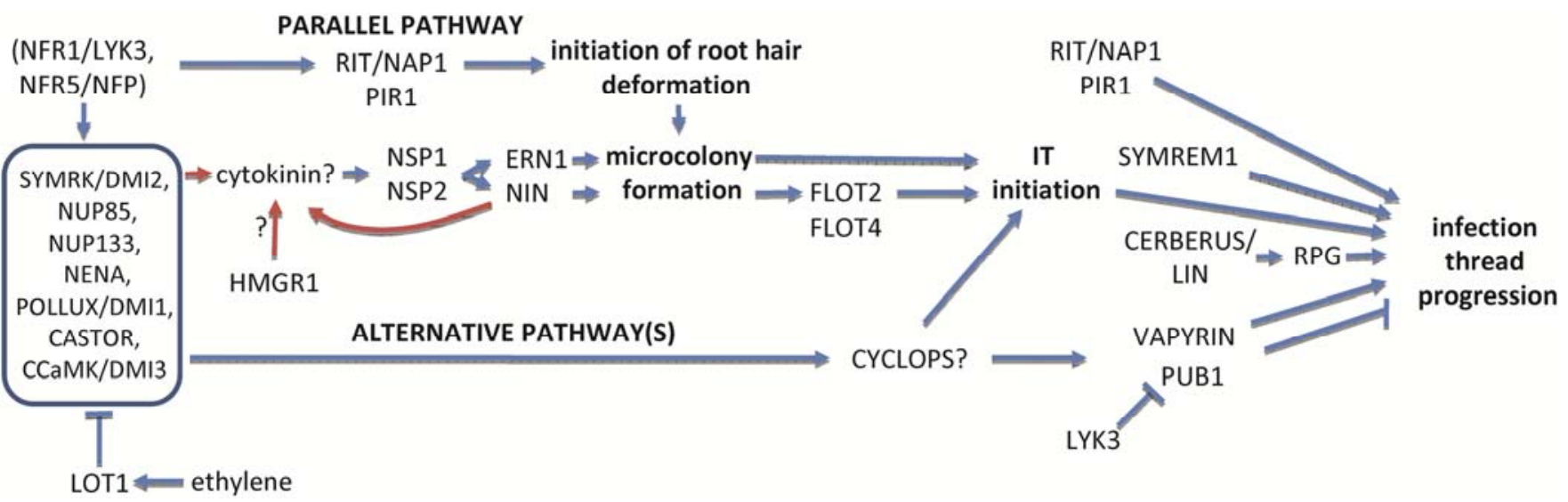

Fig. 1. Infection by rhizobia is genetically controlled by the host. Components of epidermal infection are shown using blue arrows and a proposed role for cytokinin during infection of the root cortex is shown with red arrows. The signaling pathway branches following the perception of Nod factors (NF). One signaling branch is the common symbiosis pathway which is also required for mycorrhization (SYMRK, NUP85, NUP133, NENA, DMI1/POLLUX, and CASTOR). This pathway serves to activate CCaMK and is required for NF-induced nuclear $\mathrm{Ca}^{2+}$ oscillations. Ethylene represses $\mathrm{NF}$ signaling, possibly through LOT1. The transcriptional regulators NSP1, NSP2, ERN1, and NIN are required for infection pocket formation and infection thread (IT) initiation. NSP1 and NSP2 form a heterocomplex in planta and NSP1 binds to the NIN and ERN1 promoters (Hirsch et al. 2009). NSP2 is required for the induction of NIN (Murakami et al. 2006) and NIN is required for the formation normal microcolonies and is required for the initiation of IT. A second branch, the "parallel pathway", plays an essential role and is required for root-hair deformations and the initiation and progression of IT. RIT/NAP1 and PIRI act in this pathway and have roles in root-hair curling and IT growth and may, additionally, participate in basipetal nuclear migration and other tip-growth related processes, such as vesicle trafficking during IT progression. The role of CYCLOPS in infection differs from its role in organogenesis, where it is thought to act in concert with CCaMK. During infection, CYCLOPS may act downstream of CCaMK because it is not required for the formation of microcolonies. but it is needed for IT initiation. One possibility is that CYCLOPS acts in one of the alternate pathways upstream of either VAPYRIN, PUB1, or both. FLOT2 and FLOT4 act downstream of NIN and are required for IT initiation. PUB1 expression is independent of NIN and VAPYRIN expression is independent of NSP1, $N S P 2, E R N 1$, and NIN, suggesting the existence of an alternative pathway for gene activation during infection. LYK3 may deactivate PUB1 to promote IT progression. It is not yet known which branch or branches of NF signaling control the expression of SYMREM1, RPG, and CERBERUS/LIN, which have roles in the progression of infection. 
3-kinase or phosphatidylinositol-specific phospholipase $\mathrm{C}$ inhibited root-hair curling and initiation of IT (Peleg-Grossman et al. 2007). Phosphoinositide (PI) signaling has a well-established role in other tip growth processes. Thus, NF-mediated root-hair curling and IT development may, like root hair and pollen tube growth, be mediated by PI-regulated processes, which include endocytosis and generation of reactive oxygen species and changes in $\mathrm{Ca}^{2+}$ (Lee et al. 2008; Monteiro et al. 2005; Potocky et al. 2007; Samaj et al. 2006).

In conclusion, based on the above genetic and biochemical analysis, NF-induced IT initiation and growth involves two or more pathways: the common symbiotic pathway acting through NSP1, NSP2, ERN1, and NIN, which is required primarily for the activation of CcaMK; and a parallel CCaMK-independent pathways that controls root-hair responses and may involve PI signaling (Fig. 1).

\section{Preinfection threads.}

A critical insight into the mechanism of IT was made when van Brussel and associates (1992) showed that, upon application of NF to Vicia sativa (vetch) roots, radial rows of cytoplasmic bridges form across outer cortical cells. These cytoplasmic bridges are aligned with anticlinal cell divisions in underlying cortical cells, and these preinfection structures predict the path of IT progression (Timmers et al. 1999). Preinfection threads (PIT) were also seen resulting from NF addition to $L$. japonicus roots (Niwa et al. 2001). PIT are associated with a localized degradation of the cell wall at the poles of the cytosolic bridge, which allows for passage of the IT between cells layers (van Brussel et al. 1992). The preinfection responses in epidermal and outer cortical cells are partly independent from those in the pericycle or inner cortex because purified Sinorhizobium meliloti NF failed to induce PIT but could induce CCD on $M$. sativa (Timmers et al. 1999). In addition, the $S$. meliloti $n o d F$ and nodL double mutant can form microcolonies and induce $\mathrm{CCD}$ but can rarely initiate IT on $M$. truncatula roots, which, when they do form, abort in the root hair (Ardourel et al. 1994; Limpens et al. 2003). It was recently shown that, in the snfl mutant, NF-dependent infection in the cortex does not require the known NF receptors NFR1 and NFR5, leaving open the possibility that another set of NF receptors function in the cortex (Madsen et al. 2010). A separate set of cortical NF receptors with a different sensitivity or specificity to NF could explain the observed independent responses of the epidermis and cortex observed in these earlier studies.

\section{The curious case of cortical root hairs.}

It was observed that the PIT that form after addition of NF develop a locally weakened periclinal cell wall near the cytosolic bridge similar to the local cell wall deformation associated with advancing IT (van Brussel et al. 1992). Surprisingly, NF application also induced root-hair-like structures originating from cortical cells, so-called cortical root hairs (CRH) (van Brussel et al. 1992; van Spronsen et al. 1994). CRH are also induced by rhizobia but were observed less frequently than with NF application. It was suggested that this could be due to the absence of IT; in this case, the locally weakened cell wall can serve as either a gateway for IT or a site for the formation of CRH. CRH also form under certain conditions on the root hairless 1 (rhll) mutant, which is incapable of initiating epidermal root hairs, indicating the genetic independence of roothair development in the cortex and epidermis. However, very surprisingly, it was found that $\mathrm{CRH}$ can functionally complement the root-hairless phenotype during infection by rhizobia by forming the classic shepherd's crook with enclosed infection pockets and normal IT (Karas et al. 2005). Judging from the efficacy of infection through these structures, it seems pos- sible that this is a significant mode of infection for rhizobia in situations where epidermal root-hair growth is compromised or perhaps even in regions of the root containing mature root hairs (Karas et al. 2005).

\section{What is a PIT? A role for components of the cell cycle.}

A histone (H4) gene is highly expressed in the path preceding IT development in the outer cortical cell layers of infected pea roots, in advance of and coincident with the formation of PIT (Yang et al. 1994). This $H 4$ gene transcript is specifically associated with the $\mathrm{S}$ phase of the cell division cycle in $M$. sativa suspension culture, indicating that outer cortical cells with PIT have reentered the cell cycle and, presumably, have undergone DNA replication. However, transcription of $c y c 2$, a gene that is specifically expressed in M phase of cell cycle, was not induced in these cells with PIT, indicating that these cells arrested at $\mathrm{S}$ phase without entering mitosis. However, inner cortical cells having PIT enter the cell division cycle and form nodule primordia (Yang et al. 1994). Indeed, the cytoplasmic strands traversing epidermal root-hair cells with actively growing IT described by Fournier and associates (2008) are not unlike cytoplasmic bridges formed in cortical cells during infection. Could epidermal cells also be forming PIT? In support of this notion is the observation that, during the transition from root-hair growth to IT growth, the epidermal cell nuclei nearly double in size, indicating entry into S phase (Dart 1974). Perhaps there are spatial restrictions delimited by hormone gradients that dictate whether a given cell can become mitotically engaged. In particular, it has been found that cytokinin and ethylene play significant roles in IT and nodule development.

\section{A role for cytokinin.}

Although epidermal and cortical events are clearly separable, there is a clear synchronicity of infections with underlying CCD. Cytokinin may play a role in coordinating these two programs. In L. japonicus, a cytokinin receptor mutant, lotus histidine kinase 1 (lhkl), has supernumerary infections but lacks timely cell divisions, and the IT are initially blocked at the epidermalcortical interface (Murray et al. 2007). In M. truncatula, RNAi downregulation of the $L H K 1$ ortholog $M t C r e 1$ resulted in most infections being blocked in root hairs and a clear reduction in CCD (Gonzalez-Rizzo et al. 2006). The discrepancy between the $l h k 1$ mutant and MtCREl knockdown phenotypes may represent real differences in the role of cytokinin between legume species but could also simply reflect differences in functional redundancy as they belong to a multigene family. A role for cytokinin in $M$. truncatula infection is further supported by the reduced infection phenotype in plants with reduced expression of 3-hydroxy-3-methylglutaryl CoA reductase 1 (HMGRI), an enzyme required for isoprenoid synthesis, including cytokinin (Kevei et al. 2007). Thus, cytokinin may have a role in IT formation in the outer cortex and epidermis in Lotus and Medicago spp., respectively. Cytokinin may interact with the infection and nodule development pathway through NIN. NIN expression is induced by cytokinin and, reciprocally, $N I N$ is required for the induction of MtARR4, which acts downstream of MtCRE1 during nodulation (Gonzalez-Rizzo et al. 2006; Murray et al. 2007; Tirichine et al. 2007). This suggests a positive feedback mechanism exists (Fig. 1). However, nodules that form on ccamk snf2 (snf2 is an LHK1 gain-of-function allele) double mutants fail to become colonized, indicating that LHK1/MtCRE1-mediated cytokinin signaling alone is insufficient to permit infection (Madsen et al. 2010).

It is not surprising to see the involvement of cytokinin in initiating CCD in response to NF or rhizobia because of its basic function in cell growth and division, but what role might this hormone play in IT progression? Gage and Margolin (2000) 
noted that the PIT appears as an arrested form of cell divisions occurring in the cortex during nodule formation. If PIT are analogous to phragmoplasts, it is possible that their formation could require cytokinin. This could explain the block in IT progression in Lotus $l h k l$ mutants at the cortical interface. In this scenario, the Medicago MtCRE1 knockdown phenotype could be a secondary effect; for example, Arabidopsis cytokinin receptor mutants overproduce cytokinin, which, if it occurs in $\operatorname{lhk} 1$ mutants, could negatively affect IT development through increased production of ethylene (Hansen et al. 2009; Riefler et al. 2006). Alternatively, it could suggest that cytokinin is directly required for root-hair infection. An answer to these questions will require a more detailed genetic analysis of the cytokinin receptor family and a better understanding of the events that occur downstream of cytokinin signaling during infection.

\section{Ethylene as a major regulator.}

Ethylene is able to block cell divisions in legume roots, including CCD in nodulation (Apelbaum and Burg 1972; Lee and Larue 1992), and has been shown to reduce the initiation of IT and the responses to NF, including the $\mathrm{Ca}^{2+}$ spiking associated with NF signaling (Oldroyd et al. 2001). Ethylene also inhibits PIT formation in vetch (van Spronsen et al. 1995). Increased infections are seen in the Medicago sickle (ethyleneinsensitive 2 [ein2]) mutant (Penmetsa et al. 2003, 2008) and transgenic plants having a dominant negative ethylene receptor gene, ethylene response sensor 1 (ERS1/H70A) (Nukui et al. 2004) or ethylene response 1 (ETR1-1), where ethylene sensitivity is affected (Lohar et al. 2009). Thus, ethylene plays a significant inhibitory role in rhizobial infection and nodule formation. The inhibition of infection by ethylene may be specifically mediated by LOT1. The L. japonicus mutant low nodulation and trichome distortion 1 (lot1) has reduced IT and nodule formation and is insensitive to the suppression of nodule formation by ethylene but it retains a normal triple response (Ooki et al. 2005) (Fig. 1).

However, ethylene is not always a negative factor and plays a positive role during alternative modes of infection. Ethylene is required for rhizobial infection and nodule development in Sesbania rostrata flooded roots in which the crack entry mechanism is used (Capoen et al. 2009; Goormachtig et al. 2004), and crack entry infection in the nena mutant was also dependent on ethylene (Groth et al. 2010).

In contrast to its role in IT development, ethylene is a positive regulator of root-hair growth (Tanimoto et al. 1995). This represents a major difference between the hormonal regulation of these two tip-growth processes. Notably, whereas NF-induced $\mathrm{Ca}^{2+}$ oscillations are repressible by ethylene, NF-induced root hair-tip growth is not (Heidstra et al. 1997). This further demonstrates the existence of a parallel pathway independent of the common symbiotic pathway. It's possible that, during rhizobial infection, the plant locally decreases the production of ethylene in response to NF, and this marks the switch from root-hair growth to IT initiation and growth. The root hair itself switches from an ethylene-promoted process of polarized growth to a form of inverted polar growth that is not only ethylene independent but also strongly inhibited by this hormone. Understanding the orchestration of ethylene signaling in root-hair cells during infection will undoubtedly increase our understanding of this hormone's effect on cell growth processes in general.

\section{IT PROGRESSION}

\section{More than one role for $\mathrm{Ca}^{2+}$.}

$\mathrm{Ca}^{2+}$ oscillations are induced near and within the nucleus of growing root hairs by NF earlier than the occurrence of roothair cell deformations (Ehrhardt et al. 1996; Engstrom et al.
2002; Sieberer et al. 2009). Mutants that lack these oscillations fail to form IT and nodules; therefore, it is assumed that spiking is an essential component of NF-signaling, but proof of this will require identification of the $\mathrm{Ca}^{2+}$ channels involved (Oldroyd and Downie 2006). Independent roles for $\mathrm{Ca}^{2+}$ oscillations in root-hair growth and IT growth in response to NF are possible. $\mathrm{Ca}^{2+}$ oscillation patterns are associated with polar tip growth of plant root hairs and pollen tubes (Monshausen et al. 2008; Rincon-Zachary et al. 2010). Changing of $\mathrm{Ca}^{2+}$ gradients can alter the directional growth of root-hair tip and pollen tube, and $\mathrm{Ca}^{2+}$ gradients are also important for the growth of fungal hyphae (Bibikova et al. 1997; Malho and Trewavas 1996; Silverman-Gavrila and Lew 2003). If a $\mathrm{Ca}^{2+}$ gradient is required to direct tip growth processes, it is likely to be required for both NF-induced root-hair deformation and directional IT growth. Alternatively, it has been proposed that IT formation may be a modified version of cell plate formation based on a likeness that was noted between the transcellular bridges observed in dividing cells during the formation of the phragmoplast and PIT (Brewin 2004; Kijne 1992). Cell plate formation also requires $\mathrm{Ca}^{2+}$ gradients at the plane of division (Hepler 1994). In this scenario, a local PM-localized $\mathrm{Ca}^{2+}$ gradient would be required along the length of the IT where new cell wall is being formed. Whether IT growth is better modeled as tip-growth or as a modified cell plate, it seems likely that a localized $\mathrm{Ca}^{2+}$ gradient at the interface of the growing membrane will be required. The primary role of $\mathrm{Ca}^{2+}$ in this context may be in promoting secretory vesicle fusion at the plasma membrane (Schneggenburger and Neher 2005). Where might this $\mathrm{Ca}^{2+}$ come from? One possible source would be the IT matrix, which likely would have abundant $\mathrm{Ca}^{2+}$ bound both to pectin (Rae et al. 1992; Vandenbosch et al. 1989) and rhizobial exopolysaccharides (Aslam et al. 2008). Alternatively, an intracellular source such as the vacuole or nucleus might be used.

\section{The actions of actin.}

Several studies have shown that one of the most rapid responses to NF is the rearrangement of actin in growing root hairs, with some responses occurring within 3 to 5 min (Allen et al. 1994; Cardenas et al. 1998; de Ruijter et al. 1999; Vassileva et al. 2005; Weerasinghe et al. 2003, 2005). In the tips of NFexposed root hairs, the longitudinal thick actin bundles were diminished and finer, more diffuse actin accumulated (Cardenas et al. 1998; de Ruijter et al. 1999; Weerasinghe et al. 2005; Yokota et al. 2009). The first genetic evidence implicating actin in infection growth was the L. japonicus crinkle mutant, which displayed defective growth of IT, pollen tubes, and root hairs (Tansengco et al. 2003). The mutant had swollen pollen tube tips that exhibited disorganized F-actin; however, the responsible gene has not yet been identified (Tansengco et al. 2004). The recently characterized mutants nck-associated protein 1 (napl) and $121 F$-specific p53 inducible RNA (pirl), which have defects in IT development, were shown to be mutated in genes that encode proteins involved in actin rearrangements (Miyahara et al. 2010; Yokota et al. 2009). The mutants also displayed defects in the polar growth processes of root hair and trichome development. Actin rearrangements observed in root hairs after NF application are absent in these mutants (Cardenas et al. 1998; Yokota et al. 2009). It has been shown previously that actin is required for NF-induced root-hair deformations (Miller et al. 1999). Consistent with this, the napl and pirl mutants had impaired NF-induced root-hair deformation and defects in infection pocket formation. In addition, the mutants rarely formed IT and those that did form often disintegrated, demonstrating roles for actin in the formation and maintenance of IT. Finally, IT never progressed past the epidermal layer, suggesting an absolute requirement for actin in IT devel- 
opment in the outer cortex. It us well established that actin is regulated by PI signaling acting through the activation of the Rho family of small GTPases (ROP) (Hilpela et al. 2004; Saarikangas et al. 2010). It's thought that ROP serve to generate tip-focused $\mathrm{F}$-actin and $\mathrm{Ca}^{2+}$ gradients during polar cell growth (Yang 2002). PI signaling has also been shown to be required for both root-hair curling and IT initiation (KellySkupek and Irving 2006; Peleg-Grossman et al. 2007; Saarikangas et al. 2010). These points considered, it seems plausible that actin plays a central role in PI-driven tip growth during IT progression (Fig. 1). Interestingly, long-distance intracellular movement of the nucleus has been shown to require actin but not microtubules (Chytilova et al. 2000). In addition, it has been shown that the basipetal movement of the nucleus that occurs after root-hair growth requires actin (Ketelaar et al. 2002). It is possible that the nuclear movement that normally accompanies IT growth is also deficient in these mutants.

\section{A role for lipid rafts in infection.}

Lipid rafts are membrane microdomains that act as organizing centers for signal molecule assembly. Some lipid raft complex components have recently been implicated in infection. Silencing of a group of three flotillins in the roots of $M$. truncatula plants resulted in reduced numbers of IT (Haney and Long 2010). FLOT2 and FLOT4 were found to localize to membrane microdomains, and FLOT4 was uniquely found to mobilize to infected root-hair tips. Flot 4 and Flot 2 were induced by infection and this required NIN and NSP2 but not ERN1. A nodule-specific remorin, MEDICAGO TRUNCATULA SYMBIOTIC REMORIN 1 (MtSYMREM1), was shown to be involved in infection in $M$. truncatula. Remorins are also found in lipid rafts (Jarsch and Ott 2011). Mutations in this gene caused formation of enlarged and highly branched IT within the nodule; these abnormal IT failed to release bacteria into the symbiosomes while RNAi-mediated reduction of MtSYMREM1 transcripts resulted in defective IT progression in root hairs (Lefebvre et al. 2010). Remorin also interacts with LYK3, NFP, and SYMRK in vivo, suggesting that there may be an NF-signaling complex that assembles within membrane microdomains and that this plays an essential role in the infection process.

\section{New players with unknown roles.}

Recently, several genes with roles in infection have been identified using genetics and biochemistry. In the lin and cerberus mutants, identified in M. truncatula and L. japonicus, respectively, most IT arrest in the epidermis and nodules form as small bumps but are not colonized (Kiss et al. 2009; Yano et al. 2009). Mutants lin and cerberus were found to be mutated in orthologous U-Box/WD40 genes. The U-box is found in E3 ubiquitin ligases that ubiquitinate proteins, which leads to their degradation by the $26 \mathrm{~S}$ proteasome complex, suggesting a role for LIN/CERBERUS in protein turnover. Another mutant, rpg, exhibits deficient root-hair curling and slow-progressing IT (Arrighi et al. 2008). The underlying gene was identified as a long coiled-coil protein that localizes to the nucleus, hinting at a role in transcriptional regulation. The expression of $R P G$ in lin and hcl(lyk3) mutant backgrounds was greatly reduced, suggesting that it acts downstream (Fig. 1). It has not been determined whether the transcriptional induction of $R P G$ and LIN/CERBERUS is dependent on NIN, NSP1, NSP2, and ERN1.

\section{VAPYRIN and PUB1, possible links to secretion.}

It is clear that secretion will play a central role in infection. Potential roles include protein delivery to the PM for rhizobial attachment and NF signaling and secretion to the apoplast for cell wall degradation at the site of IT initiation. In addition, the polarized growth of the IT will require vesicle-mediated delivery of cell wall components and specialized matrix proteins (Rae et al. 1992; Vandenbosch et al. 1989). Recently, a couple of genes with possible links to secretion during infection have been identified. VAPYRIN (VPY) is required for mycorrhizal infection and arbuscule development (Feddermann et al. 2010; Pumplin et al. 2010) as well as the development of IT (Murray et al. 2011). The vpy mutants have enlarged and misshapen IT that abort in root hairs. VPY is inducible by NF and this induction is dependent on $C C a M K$ but not on NIN, revealing the existence of a NIN-independent pathway required for infection (Fig. 1). VPY encodes a protein containing a major-sperm (MSP) domain (also called a VAP domain) and an ankyrin repeat domain. A possible link of $V P Y$ with secretion comes from a well-studied MSP-containing protein in humans, VAP33, which interacts with a SNAREcomplex member to regulate the exocyst-dependent secretion of glucose transporters in response to insulin. The exocyst is an octameric complex that tethers vesicles prior to SNARE complex fusion during exocytosis (Zhang et al. 2010). Another recently discovered protein, PUB1, may also have links to exocytosis. PUB1 is a demonstrated E3 ubiquitin ligase, which was detected using a two-hybrid screen for LYK3 interactors (Mbengue et al. 2010). PUB1 is phosphorylated by the kinase domain of LYK3, and RNAi knockdown of PUB1 transcripts increased the frequency of infections on a weak allele of $l y k 3$, providing evidence that PUB1 is a negative regulator of infection. Like $V P Y$, induction of $P U B 1$ transcripts by NF required CCaMK but not NIN (Fig. 1). Mbengue and associates (2010) point out that an Arabidopsis homolog of PUB1, ARC1, which also interacts with a receptor kinase (SRK1), has been shown to interact with an exocyst complex member EXO70A1. One exciting possibility is that VAPYRIN or PUB1 play a role in the regulation of NF-dependent secretion. The MtGEA database reveals that at least two EXO70 genes are highly expressed during nodulation. In Arabidopsis, two EXO70 family members (EXO70A1 and EXO70C1) are required for polarized growth processes (Li et al. 2010; Synek et al. 2006). Identification of the components of the plant secretion systems required for infection and the cargo they deliver is needed to better understand rhizobial attachment and entry and the formation and initiation of IT. What controls the change from secretion driving polar growth of root hairs to that of IT progression? Does LYK3 mediate NFdependent secretion through PUB1? Is the exocyst required for IT initiation or growth? More genetic and biochemical studies are needed to identify the key players and to reveal how they are interlinked.

\section{FUTURE DIRECTIONS}

\section{Sequencing the infectome.}

A combination of deep sequencing technologies (RNA-seq) and microarrays has recently been used to characterize the gene expression of rhizobially infected root hairs in soybean (Libault et al. 2010). More than 1,900 differentially regulated genes were identified, the large number likely reflecting the increased resolution of this approach compared with harvesting the entire root. Many known symbiotic genes were found to be upregulated in root hairs from infected plants, including homologs of NFR1, NFR5, NIN, and NSP1 and NSP2, supporting the proposed role of these genes in infection. This approach will prove especially powerful in model legumes, and similar root-hair-based expression analysis of infection mutants combined with techniques to isolate specific cell types such as laser-capture microdissection and fluorescence-activated cell sorting will help create a better understanding of gene expression changes during infection. 


\section{Forward and reverse genetics.}

The identification of new infection mutants in L. japonicus promises rapid progress in this area in the upcoming years (Lombardo et al. 2006; Murray et al. 2006; Yano et al. 2006). The growing collection of publicly available gene expression data (Benedito et al. 2008; He et al. 2009) will serve to lay the ground for reverse genetic studies in both Medicago and Lotus spp. (Le Signor et al. 2009; Rogers et al. 2009; Till et al. 2003). In particular, Medicago spp. benefit from a large collection of Tnt1-transposon insertion lines (Tadege et al. 2008).

\section{Imaging the IT.}

The rhizobial IT is a unique structure that has captured the imagination of many researchers since it was first observed in 1887 (Ward 1887). As a superficial cell layer, root hairs present an attractive object of study. Recent efforts by (Fournier et al. 2008) have identified a fluorescent marker that can reveal the plasma membrane around the IT. In addition, they showed that a marker for the endoplasmic reticulum can effectively highlight the cytoplasmic bridge between the IT tip and the nucleus. These present powerful tools for the study of infection mutants but other markers are needed to highlight specific membrane trafficking processes such as exo and endocytosis that must play a central role. A combination of improved imaging techniques and genetics will help unravel the regulatory and physiological processes behind IT initiation and progression to shed light on the relationship in this special system of coordinated signaling and tip growth.

\section{ACKNOWLEDGMENTS}

I thank A. Downie, G Oldroyd, and P. Xu for critiquing the manuscript and members of the Downie and Oldroyd labs for useful discussions during the Yorkshire retreat. This work was supported by the Biotechnology and Biological Sciences Research Council fellowship BB/G023832/1.

\section{LITERATURE CITED}

Allen, N. S., Bennett, M. N., Cox, D. N., Shipley, A., Ehrhardt, D. W., and Long, S. R. 1994. Effects of Nod factors on alfalfa root-hair $\mathrm{Ca}^{++}$and $\mathrm{H}^{+}$currents and on cytoskeletal behavior. Pages 107-114 in: Advances in Molecular Genetics of Plant-Microbe Interactions, Vol. 3. M. G. Daniels, J. A. Downie, and A. E. Osbourne, eds. Kluwer Academic Pub., Dordrecht, The Netherlands.

Amor, B. B., Shaw, S. L., Oldroyd, G. E., Maillet, F., Penmetsa, R. V., Cook, D., Long, S. R., Denarie, J., and Gough, C. 2003. The NFP locus of Medicago truncatula controls an early step of Nod factor signal transduction upstream of a rapid calcium flux and root hair deformation. Plant J. 34:495-506.

Andriankaja, A., Boisson-Demier, A., Frances, L., Sauviac, L., Jauneau, A., Barker, D. G., and de Carvalho-Niebel, F. 2007. AP2-ERF transcription factors mediate nod factor-dependent mtENOD11 activation in root hairs via a novel cis-regulatory motif. Plant Cell 19:2866-2885.

Apelbaum, A., and Burg, S. P. 1972. Effect of ethylene on cell division and deoxyribonucleic acid synthesis in Pisum sativum. Plant Physiol. 50:117-124.

Ardourel, M., Demont, N., Debelle, F., Maillet, F., de Billy, F., Prome, J. C., Denarie, J., and Truchet, G. 1994. Rhizobium meliloti lipooligosaccharide nodulation factors: different structural requirements for bacterial entry into target root hair cells and induction of plant symbiotic developmental responses. Plant Cell 6:1357-1374.

Arrighi, J. F., Barre, A., Ben Amor, B., Bersoult, A., Soriano, L. C., Mirabella, R., de Carvalho-Niebel, F., Journet, E. P., Gherardi, M., Huguet, T., Geurts, R., Denarie, J., Rouge, P., and Gough, C. 2006. The Medicago truncatula lysine motif-receptor-like kinase gene family includes NFP and new nodule-expressed genes. Plant Physiol. 142:265279.

Arrighi, J. F., Godfroy, O., de Billy, F., Saurat, O., Jauneau, A., and Gough, C. 2008. The RPG gene of Medicago truncatula controls Rhizobium-directed polar growth during infection. Proc. Natl. Acad. Sci. U.S.A. 105:9817-9822.

Aslam, S. N., Newman, M. A., Erbs, G., Morrissey, K. L., Chinchilla, D., Boller, T., Jensen, T. T., De Castro, C., Ierano, T., Molinaro, A., Jackson,
R. W., Knight, M. R., and Cooper, R. M. 2008. Bacterial polysaccharides suppress induced innate immunity by calcium chelation. Curr. Biol. 18:1078-1083.

Benedito, V. A., Torres-Jerez, I., Murray, J. D., Andriankaja, A., Allen, S. Kakar, K., Wandrey, M., Verdier, J., Zuber, H., Ott, T., Moreau, S., Niebel, A., Frickey, T., Weiller, G., He, J., Dai, X., Zhao, P. X., Tang, Y., and Udvardi, M. K. 2008. A gene expression atlas of the model legume Medicago truncatula. Plant J. 55:504-513.

Bibikova, T. N., Zhigilei, A., and Gilroy, S. 1997. Root hair growth in Arabidopsis thaliana is directed by calcium and an endogenous polarity. Planta 203:495-505.

Brewin, N. J. 2004. Plant cell wall remodelling in the Rhizobium-legume symbiosis. Crit. Rev. Plant Sci. 23:293-316.

Capoen, W., Oldroyd, G., Goormachtig, S., and Holsters, M. 2009. Sesbania rostrata: a case study of natural variation in legume nodulation. New Phytol. 186:340-345.

Cardenas, L., Vidali, L., Dominguez, J., Perez, H., Sanchez, F., Hepler, P. K., and Quinto, C. 1998. Rearrangement of actin microfilaments in plant root hairs responding to Rhizobium etli nodulation signals. Plant Physiol. 116:871-877.

Catoira, R., Galera, C., de Billy, F., Penmetsa, R. V., Journet, E. P., Maillet, F., Rosenberg, C., Cook, D., Gough, C., and Denarie, J. 2000. Four genes of Medicago truncatula controlling components of a nod factor transduction pathway. Plant Cell 12:1647-1666.

Charpentier, M., Bredemeier, R., Wanner, G., Takeda, N., Schleiff, E., and Parniske, M. 2008. Lotus japonicus CASTOR and POLLUX are ion channels essential for perinuclear calcium spiking in legume root endosymbiosis. Plant Cell 20:3467-3479.

Chytilova, E., Macas, J., Sliwinska, E., Rafelski, S.M., Lambert, G. M., and Galbraith, D. W. 2000. Nuclear dynamics in Arabidopsis thaliana. Mol. Biol. Cell 11:2733-2741.

Dart P. J. 1974. The infection process. Chapter 11.1 in: The Biology of Nitrogen Fixation. A. Quispel, ed. North-Holland Publishing Co., Amsterdam.

de Ruijter, N. C. A., Bisseling, T., and Emons, A. M. C. 1999. Rhizobium Nod factors induce an increase in sub-apical fine bundles of actin filaments in Vicia sativa root hairs within minutes. Mol. Plant-Microbe Interact. 12:829-832.

Downie, J. A. 2010. The roles of extracellular proteins, polysaccharides and signals in the interactions of rhizobia with legume roots. FEMS (Fed. Eur. Microbiol. Soc.) Microbiol. Rev. 34:150-170.

Ehrhardt, D. W., Wais, R., and Long, S. R. 1996. Calcium spiking in plant root hairs responding to Rhizobium nodulation signals. Cell 85:673681.

Endre, G., Kereszt, A., Kevei, Z., Mihacea, S., Kalo, P., and Kiss, G. B. 2002. A receptor kinase gene regulating symbiotic nodule development. Nature 417:962-966.

Engstrom, E. M., Ehrhardt, D. W., Mitra, R. M., and Long, S. R. 2002. Pharmacological analysis of nod factor-induced calcium spiking in Medicago truncatula. Evidence for the requirement of type IIA calcium pumps and phosphoinositide signaling. Plant Physiol. 128:1390-1401.

Esseling, J. J., Lhuissier, F. G., and Emons, A. M. 2004. A nonsymbiotic root hair tip growth phenotype in $N O R K$-mutated legumes: implications for nodulation factor-induced signaling and formation of a multifaceted root hair pocket for bacteria. Plant Cell 16:933-944.

Feddermann, N., Muni, R. R. D., Zeier, T., Stuurman, J., Ercolina, F., Schordereta, M., and Reinhardt, D. 2010. Intracellular accommodation and morphogenesis of arbuscular mycorrhizal fungi in petunia requires a conserved ankyrin-related protein. Plant J. 64:470-481.

Fournier, J., Timmers, A. C., Sieberer, B. J., Jauneau, A., Chabaud, M., and Barker, D. G. 2008. Mechanism of infection thread elongation in root hairs of Medicago truncatula and dynamic interplay with associated rhizobial colonization. Plant Physiol. 148:1985-1995.

Gage, D. J. 2004. Infection and invasion of roots by symbiotic, nitrogenfixing rhizobia during nodulation of temperate legumes. Microbiol. Mol.. Biol. Rev. 68:280-300.

Gage, D. J., and Margolin, W. 2000. Hanging by a thread: invasion of legume plants by rhizobia. Curr. Opin. Microbiol. 3:613-617.

Gonzalez-Rizzo, S., Crespi, M., and Frugier, F. 2006. The Medicago truncatula CRE1 cytokinin receptor regulates lateral root development and early symbiotic interaction with Sinorhizobium meliloti. Plant Cell 18:2680-2693.

Goormachtig, S., Capoen, W., and Holsters, M. 2004. Rhizobium infection: lessons from the versatile nodulation behaviour of water-tolerant legumes. Trends Plant Sci. 9:518-522.

Groth, M., Takeda, N., Perry, J., Uchida, H., Dräxl, S., Brachmann, A., Sato, S., Tabata, S., Kawaguchi, M., Wang, T. L., and Parniske, M. 2010 NENA, a Lotus japonicus homolog of Sec13, is required for rhizodermal infection by arbuscular mycorrhiza fungi and rhizobia but dispensable for cortical endosymbiotic development. Plant Cell 22:2509-2526. 
Guinel, F. C., and Geil, R. D. 2002. A model for the development of the rhizobial and arbuscular mycorrhizal symbioses in legumes and its use to understand the roles of ethylene in the establishment of these two symbioses. Can. J. Bot. 80:695-720.

Haney, C. H., and Long, S. R. 2010. Plant flotillins are required for infection by nitrogen-fixing bacteria. Proc. Natl. Acad. Sci. U.S.A. 107:478483.

Hansen, M., Chae, H. S., and Kieber, J. J. 2009. Regulation of ACS protein stability by cytokinin and brassinosteroid. Plant J. 57:606-614

Hayashi, T., Banba, M., Shimoda, Y., Kouchi, H., Hayashi, M., and Imaizumi-Anraku, H. 2010. A dominant function of CCaMK in intracellular accommodation of bacterial and fungal endosymbionts. Plant J. 63:141-154.

He, J., Benedito, V. A., Wang, M., Murray, J. D., Zhao, P. X., Tang, Y., and Udvardi, M. K. 2009. The Medicago truncatula gene expression atlas web server. BMC Bioinf. 10:441.

Heckmann, A. B., Lombardo, F., Miwa, H., Perry, J. A., Bunnewell, S. Parniske, M., Wang, T. L., and Downie, J. A. 2006. Lotus japonicus nodulation requires two GRAS domain regulators, one of which is functionally conserved in a non-legume. Plant Physiol. 142:1739-1750.

Heidstra, R., Geurts, R., Franssen, H., Spaink, H. P., Van Kammen, A., and Bisseling, T. 1994. Root hair deformation activity of nodulation factors and their fate on Vicia sativa. Plant Physiol. 105:787-797.

Heidstra, R., Yang, W. C., Yalcin, Y., Peck, S., Emons, A..M., van Kammen, A., and Bisseling, T. 1997. Ethylene provides positional information on cortical cell division but is not involved in Nod factorinduced root hair tip growth in Rhizobium-legume interaction. Development 124:1781-1787.

Hepler, P. K 1994. The role of calcium in cell division. Cell Calcium 16:322-330.

Hilpela, P., Vartiainen, M. K., and Lappalainen, P. 2004. Regulation of the actin cytoskeleton by $\mathrm{PI}(4,5) \mathrm{P}-2$ and $\mathrm{PI}(3,4,5) \mathrm{P}-3$. Curr. Top. Microbiol. 282:117-163.

Hirsch, S., Kim J., Muñoz, A., Heckmann, A. B., Downie, J. A., and Oldroyd, G. E. D. 2009. GRAS proteins form a DNA binding complex to induce gene expression during nodulation signaling in Medicago truncatula. Plant Cell 21:545-557.

Imaizumi-Anraku, H., Takeda, N., Charpentier, M., Perry, J., Miwa, H., Umehara, Y., Kouchi, H., Murakami, Y., Mulder, L., Vickers, K., Pike, J., Downie, J. A., Wang, T., Sato, S., Asamizu, E., Tabata, S., Yoshikawa, M., Murooka, Y., Wu, G. J., Kawaguchi, M., Kawasaki, S., Parniske, M., and Hayashi, M. 2005. Plastid proteins crucial for symbiotic fungal and bacterial entry into plant roots. Nature 433:527-531

Jarsch, I. K., and Ott, T. 2011. Perspectives on remorin proteins, membrane rafts, and their role during plant-microbe interactions. Mol. PlantMicrobe Interact. 24:7-12.

Jones, K. M., Kobayashi, H., Davies, B. W., Taga, M. E., and Walker, G C. 2007. How rhizobial symbionts invade plants: the SinorhizobiumMedicago model. Nat. Rev. Microbiol. 5:619-633.

Kalo, P., Gleason, C., Edwards, A., Marsh, J., Mitra, R. M., Hirsch, S., Jakab, J., Sims, S., Long, S. R., Rogers, J., Kiss, G. B., Downie, J. A., and Oldroyd, G. E. 2005. Nodulation signaling in legumes requires NSP2, a member of the GRAS family of transcriptional regulators. Science 308:1786-1789.

Kanamori, N., Madsen, L. H., Radutoiu, S., Frantescu, M., Quistgaard, E. M., Miwa, H., Downie, J. A., James, E. K., Felle, H. H., Haaning, L. L. Jensen, T. H., Sato, S., Nakamura, Y., Tabata, S., Sandal, N., and Stougaard, J. 2006. A nucleoporin is required for induction of $\mathrm{Ca}^{2+}$ spiking in legume nodule development and essential for rhizobial and fungal symbiosis. Proc. Natl. Acad. Sci. U.S.A. 103:359-364.

Karas, B., Murray, J., Gorzelak, M., Smith, A., Sato, S., Tabata, S., and Szczyglowski, K. 2005. Invasion of Lotus japonicus root hairless 1 by Mesorhizobium loti involves the nodulation factor-dependent induction of root hairs. Plant Physiol. 137:1331-1344.

Kelly-Skupek, M. N., and Irving, H. R. 2006. Pharmacological evidence for activation of phospholipid and small GTP binding protein signalling cascades by Nod factors. Plant Physiol. Biochem. 44:132-142.

Ketelaar, T., Faivre-Moskalenko, C., Esseling, J. J., de Ruijter, N. C. A., Grierson, C. S., Dogterom, M., and Emons, A. M. C. 2002. Positioning of nuclei in Arabidopsis root hairs: an actin-regulated process of tip growth. Plant Cell 14:2941-2955.

Kevei, Z., Lougnon, G., Mergaert, P., Horvath, G. V., Kereszt, A., Jayaraman, D., Zaman, N., Marcel, F., Regulski, K., Kiss, G. B., Kondorosi, A., Endre, G., Kondorosi, E., and Ane, J. M. 2007. 3Hydroxy-3-methylglutaryl coenzyme a reductase 1 interacts with NORK and is crucial for nodulation in Medicago truncatula. Plant Cell 19:3974-3989.

Kijne, J. W. 1992. The Rhizobium infection process. Pages 349-398 in: Biological Nitrogen Fixation. G. Stacey, R. H. Burris, and H. J. Evans, eds. Chapman and Hall, New York.
Kiss, E., Olah, B., Kalo, P., Morales, M., Heckmann, A. B., Borbola, A., Lozsa, A., Kontar, K., Middleton, P., Downie, J. A., Oldroyd, G. E., and Endre, G. 2009. LIN, a novel type of U-box/WD40 protein, controls early infection by rhizobia in legumes. Plant Physiol. 151:1239-1249.

Kistner, C., Winzer, T., Pitzschke, A., Mulder, L., Sato, S., Kaneko, T., Tabata, S., Sandal, N., Stougaard, J., Webb, K. J., Szczyglowski, K., and Parniske, M. 2005. Seven Lotus japonicus genes required for transcriptional reprogramming of the root during fungal and bacterial symbiosis. Plant Cell 17:2217-2229.

Kouchi, H., Imaizumi-Anraku, H., Hayashi, M., Hakoyama, T., Nakagawa, T., Umehara, Y., Suganuma, N., and Kawaguchi, M. 2010. How many peas in a pod? Legume genes responsible for mutualistic symbioses underground. Plant Cell Physiol. 51:1381-1397.

Lee, K. H., and Larue, T. A. 1992. Exogenous ethylene inhibits nodulation of Pisum sativum L. cv. Sparkle. Plant Physiol. 100:1759-1763.

Lee, Y., Bak, G., Choi, Y., Chuang, W. I., Cho, H. T., and Lee, Y. 2008. Roles of phosphatidylinositol 3-kinase in root hair growth. Plant Physiol. 147:624-635.

Lefebvre, B., Timmers, T., Mbengue, M., Moreau, S., Herve, C., Toth, K., Bittencourt-Silvestre, J., Klaus, D., Deslandes, L., Godiard, L., Murray, J. D., Udvardi, M. K., Raffaele, S., Mongrand, S., Cullimore, J., Gamas, P., Niebel, A., and Ott, T. 2010. A remorin protein interacts with symbiotic receptors and regulates bacterial infection. Proc. Natl. Acad. Sci. U.S.A. 107:2343-2348.

Le Signor, C., Savois, V., Aubert, G., Verdier, J., Nicolas, M., Pagny, G., Moussy, F., Sanchez, M., Baker, D., Clarke, J., and Thompson, R. 2009. Optimizing TILLING populations for reverse genetics in Medicago truncatula. Plant Biotechnol. J. 7:430-441.

Levy, J., Bres, C., Geurts, R., Chalhoub, B., Kulikova, O., Duc, G., Journet, E. P., Ane, J. M., Lauber, E., Bisseling, T., Denarie, J., Rosenberg, C., and Debelle, F. 2004. A putative $\mathrm{Ca}^{2+}$ and calmodulin-dependent protein kinase required for bacterial and fungal symbioses. Science 303:1361-1364

Li, S., van Os, G. M. A., Ren, S., Yu, D., Ketelaar, T., Emons, A. M. C., and Liu, C. 2010. Expression and functional analyses of EXO70 genes in Arabidopsis implicate their roles in regulating cell type-specific exocytosis. Plant Physiol. 154:1819-1830.

Libault, M., Farmer, A., Brechenmacher, L., Drnevich, J., Langley, R. J. Bilgin, D. D., Radwan, O., Neece, D. J., Clough, S. J., May, G. D., and Stacey, G. 2010. Complete transcriptome of the soybean root hair cell, a single-cell model, and its alteration in response to Bradyrhizobium japonicum infection. Plant Physiol. 152:541-552.

Limpens, E., Franken, C., Smit, P., Willemse, J., Bisseling, T., and Geurts R. 2003. LysM domain receptor kinases regulating rhizobial Nod factor-induced infection. Science 302:630-633.

Lohar, D., Stiller, J., Kam, J., Stacey, G., and Gresshoff, P. M. 2009. Ethylene insensitivity conferred by a mutated Arabidopsis ethylene receptor gene alters nodulation in transgenic Lotus japonicus. Ann. Bot 104:277-285

Lombardo, F., Heckmann, A. B., Miwa, H., Perry, J. A., Yano, K., Hayashi, M., Parniske, M., Wang, T. L., and Downie, J. A. 2006. Identification of symbiotically defective mutants of Lotus japonicus affected in infection thread growth. Mol. Plant-Microbe Interact. 19:1444-1450.

Madsen, E. B., Madsen, L. H., Radutoiu, S., Olbryt, M., Rakwalska, M., Szczyglowski, K., Sato, S., Kaneko, T., Tabata, S., Sandal, N., and Stougaard, J. 2003. A receptor kinase gene of the LysM type is involved in legume perception of rhizobial signals. Nature 425:637-640.

Madsen, L. H., Tirichine, L., Jurkiewicz, A., Sullivan, J. T., Heckmann, A. B., Bek, A. S., Ronson, C. W., James, E. K., and Stougaard, J. 2010 The molecular network governing nodule organogenesis and infection in the model legume Lotus japonicus. Nat. Commun. 1:1-12.

Malho, R., and Trewavas, A. J. 1996. Localized apical increases of cytosolic free calcium control pollen tube orientation. Plant Cell 8:1935-1949.

Marsh, J. F., Rakocevic, A., Mitra, R. M., Brocard, L., Sun, J., Eschstruth, A., Long, S. R., Schultze, M., Ratet, P., and Oldroyd, G. E. 2007. Medicago truncatula NIN is essential for rhizobial-independent nodule organogenesis induced by autoactive calcium/calmodulin-dependent protein kinase. Plant Physiol 144:324-335.

Mbengue, M., Camut, S., de Carvalho-Niebel, F., D., Solène Froidure, L., Klaus-Heisen, D., Moreau, S., Rivas, S., Timmers, T., Hervé, C., Cullimore, J., and Lefebvre, B. 2010. The Medicago truncatula E3 ubiquitin ligase PUB1 interacts with the LYK3 symbiotic receptor and negatively regulates infection and nodulation. Plant Cell 22:3474-3488.

Messinese, E., Mun, J. H., Yeun, L. H., Jayaraman, D., Rougé, P., Barre A., Lougnon, G,, Schornack, S., Bono, J. J., Cook, D. R., and Ané, J. M. 2007. A novel nuclear protein interacts with the symbiotic DMI3 calcium- and calmodulin-dependent protein kinase of Medicago truncatula. Mol. Plant-Microbe Interact. 20:912-21.

Middleton, P. H., Jakab, J., Penmetsa, R. V., Starker, C. G., Doll, J., Kalo, P., Prabhu, R., Marsh, J. F., Mitra, R. M., Kereszt, A., Dudas, B., 
VandenBosch, K., Long, S. R., Cook, D. R., Kiss, G. B., and Oldroyd, G. E. 2007. An ERF transcription factor in Medicago truncatula that is essential for Nod factor signal transduction. Plant Cell 19:1221-1234.

Miller, D. D., de Ruijter, N. C. A., Bisseling, T., and Emons, A. M. C. 1999. The role of actin in root hair morphogenesis: studies with lipochito-oligosaccharide as a growth stimulator and cytochalasin as an actin perturbing drug. Plant J. 17:141-154.

Mitra, R. M., Gleason, C. A., Edwards, A., Hadfield, J., Downie, J. A., Oldroyd, G. E. D., and Long, S. R. 2004. A Ca ${ }^{2+} /$ calmodulin-dependent protein kinase required for symbiotic nodule development: gene identification by transcript-based cloning. Proc. Natl. Acad. Sci. U.S.A. 101:4701-4705.

Miwa, H., Sun, J., Oldroyd, G. E., and Downie, J. A. 2006. Analysis of Nod-factor-induced calcium signaling in root hairs of symbiotically defective mutants of Lotus japonicus. Mol. Plant-Microbe Interact. 19:914-923.

Miyahara, A., Richens, J., Starker, C., Morieri, G., Smith, L., Long, S., Downie, J. A., and Oldroyd, G. E. D. 2010. Conservation in function of a SCAR/WAVE component during infection thread and root hair growth in Medicago truncatula, Mol. Plant-Microbe Interact. 23:1553-1562.

Monshausen, G. B., Messerli, M. A., and Gilroy, S. 2008. Imaging of the Yellow Cameleon 3.6 indicator reveals that elevations in cytosolic $\mathrm{Ca}^{2+}$ follow oscillating increases in growth in root hairs of Arabidopsis. Plant Physiol. 147:1690-1698.

Monteiro, D., Liu, Q. L., Lisboa, S., Scherer, G. E. F., Quader, H., and Malho, R. 2005. Phosphoinositides and phosphatidic acid regulate pollen tube growth and reorientation through modulation of $\left[\mathrm{Ca}^{2+}\right]_{\mathrm{c}}$ and membrane secretion. J. Exp. Bot. 56:1665-1674.

Murakami, Y., Miwa, H., Imaizumi-Anraku, H., Kouchi, H., Downie, J. A., Kawaguchi, M., and Kawasaki, S. 2006. Positional cloning identifies Lotus japonicus NSP2, a putative transcription factor of the GRAS family, required for NIN and ENOD40 gene expression in nodule initiation. DNA Res. 13:255-265.

Murray, J., Karas, B., Ross, L., Brachmann, A., Wagg, C., Geil, R., Perry, J., Nowakowski, K., MacGillivary, M., Held, M., Stougaard, J., Peterson, L., Parniske, M., and Szczyglowski, K. 2006. Genetic suppressors of the Lotus japonicus harl-1 hypernodulation phenotype. Mol. PlantMicrobe Interact. 19:1082-1091.

Murray, J. D., Karas, B. J., Sato, S., Tabata, S., Amyot, L., and Szczyglowski, K. 2007. A cytokinin perception mutant colonized by Rhizobium in the absence of nodule organogenesis. Science 315:101104.

Murray, J. D., Muni, R. R. D., Torres-Jerez, I., Tang, Y., Allen, S., Andriankaja, M., Li, G., Laxmi, A., Cheng, X., Wen, J., Vaughan, D., Schultze, M., Sun, J., Charpentier, M., Oldroyd, G., Tadege, M., Ratet, P., Mysore, K. S., Chen, R., and Udvardi, M. K. 2011. Vapyrin, a gene essential for intracellular progression of arbuscular mycorrhizal symbiosis, is also essential for infection by rhizobia in the nodule symbiosis of Medicago truncatula. Plant J. 65:244-252.

Niwa, S., Kawaguchi, M., Imazumi-Anraku, H., Chechetka, S. A., Ishizaka, M., Ikuta, A., and Kouchi, H. 2001. Responses of a model legume Lotus japonicus to lipochitin oligosaccharide nodulation factors purified from Mesorhizobium loti JRL501. Mol. Plant-Microbe Interact. $14: 848-856$

Nukui, N., Ezura, H., and Minamisawa, K. 2004. Transgenic Lotus japoni-


of infection threads and nodule primordia. Plant Cell Physiol. 45:427435

Oldroyd, G. E., and Long, S. R. 2003. Identification and characterization of nodulation-signaling pathway 2, a gene of Medicago truncatula involved in Nod factor signaling. Plant Physiol. 131:1027-1032.

Oldroyd, G. E., Engstrom, E. M., and Long, S. R. 2001. Ethylene inhibits the Nod factor signal transduction pathway of Medicago truncatula. Plant Cell 13:1835-1849.

Oldroyd, G. E. D., and Downie, J. A. 2006. Nuclear calcium changes at the core of symbiosis signalling. Curr. Opin. Plant Biol. 9:351-357.

Oldroyd, G. E. D., and Downie, J. M. 2008. Coordinating nodule morphogenesis with rhizobial infection in legumes. Annu. Rev. Plant Biol. 59:519-546

Ooki, Y., Banba, M., Yano, K., Maruya, J., Sato, S., Tabata, S., Saeki, K., Hayashi, M., Kawaguchi, M., Izui, K., and Hata, S. 2005. Characterization of the Lotus japonicus symbiotic mutant lot 1 that shows a reduced nodule number and distorted trichomes. Plant Physiol. 137:1261-1271.

Peleg-Grossman, S., Volpin, H., and Levine, A. 2007. Root hair curling and Rhizobium infection in Medicago truncatula are mediated by phosphatidylinositide-regulated endocytosis and reactive oxygen species. J. Exp. Bot. 58:1637-1649.

Penmetsa, R. V., Frugoli, J. A., Smith, L. S., Long, S. R., and Cook, D. R. 2003. Dual genetic pathways controlling nodule number in Medicago truncatula. Plant Physiol. 131:998-1008.
Penmetsa, R. V., Uribe, P., Anderson, J., Lichtenzveig, J., Gish, J. C., Nam, Y. W., Engstrom, E., Xu, K., Sckisel, G., Pereira, M., Baek, J. M., Lopez-Meyer, M., Long, S. R., Harrison, M. J., Singh, K. B., Kiss, G. B., and Cook, D. R. 2008. The Medicago truncatula ortholog of Arabidopsis EIN2, sickle, is a negative regulator of symbiotic and pathogenic microbial associations. Plant J. 55:580-595.

Potocky, M., Jones, M. A., Bezvoda, R., Smirnoff, N., and Zarsky, V. 2007. Reactive oxygen species produced by NADPH oxidase are involved in pollen tube growth. New Phytol. 174:742-751.

Pumplin, N., Mondo, S. J., Topp, S., Starker, C. G., Gantt, J. S., and Harrison, M. J. 2010. Medicago truncatula Vapyrin is a novel protein required for arbuscular mycorrhizal symbiosis. Plant J. 61:482-494.

Radutoiu, S., Madsen, L. H., Madsen, E. B., Felle, H. H., Umehara, Y, Grønlund, M., Sato, S., Nakamura, Y., Tabata, S., Sandal, N., and Stougaard, J. 2003. Plant recognition of symbiotic bacteria requires two LysM receptor-like kinases. Nature 425:585-592.

Rae, A. L., Bonfantefasolo, P., and Brewin, N. J. 1992. Structure and growth of infection threads in the legume symbiosis with Rhizobium leguminosarum. Plant J. 2:385-395.

Riefler, M., Novak, O., Strnad, M., and Schmulling, T. 2006. Arabidopsis cytokinin receptor mutants reveal functions in shoot growth, leaf senescence, seed size, germination, root development, and cytokinin metabolism. Plant Cell 18:40-54.

Rincon-Zachary, M., Teaster, N. D., Sparks, J. A., Valster, A. H., Motes, C. M., and Blancaflor, E. B. 2010. Fluorescence resonance energy transfer-sensitized emission of yellow cameleon 3.60 reveals root zone-specific calcium signatures in Arabidopsis in response to aluminum and other trivalent cations. Plant Physiol. 152:1442-1458.

Rogers, C., Wen, J., Chen, R., and Oldroyd, G. 2009. Deletion-based reverse genetics in Medicago truncatula. Plant Physiol. 151:1077-1086.

Saarikangas, J., Zhao, H. X., and Lappalainen, P. 2010. Regulation of the actin cytoskeleton-plasma membrane interplay by phosphoinositides. Physiol. Rev. 90:259-289.

Saito, K., Yoshikawa, M., Yano, K., Miwa, H., Uchida, H., Asamizu, E., Sato, S., Tabata, S., Imaizumi-Anraku, H., Umehara, Y., Kouchi, H., Murooka, Y., Szczyglowski, K., Downie, J. A., Parniske, M., Hayashi, M., and Kawaguchi, M. 2007. NUCLEOPORIN85 is required for calcium spiking, fungal and bacterial symbioses, and seed production in Lotus japonicus. Plant Cell 19:610-624.

Samaj, J., Muller, J., Beck, M., Bohm, N., and Menzel, D. 2006. Vesicular trafficking, cytoskeleton and signalling in root hairs and pollen tubes. Trends Plant Sci. 11:594-600.

Schneggenburger, R., and Neher, E. 2005. Presynaptic calcium and control of vesicle fusion, Curr. Opin. Neurobiol. 15:266-274.

Sieberer, B. J., Chabaud, M., Timmers, A. C., Monin, A., Fournier, J., and Barker, D. G. 2009. A nuclear-targeted cameleon demonstrates intranuclear $\mathrm{Ca}^{2+}$ spiking in Medicago truncatula root hairs in response to rhizobial nodulation factors. Plant Physiol. 151:1197-1206.

Silverman-Gavrila, L. B., and Lew, R. R. 2003. Calcium gradient dependence of Neurospora crassa hyphal growth. Microbiology 149:24752485.

Smit, P., Raedts, J., Portyanko, V., Debelle, F., Gough, C., Bisseling, T., and Geurts, R. 2005. NSP1 of the GRAS protein family is essential for rhizobial Nod factor-induced transcription. Science 308:1789-1791.

Stracke, S., Kistner, C., Yoshida, S., Mulder, L., Sato, S., Kaneko, T., Tabata, S., Sandal, N., Stougaard, J., Szczyglowski, K., and Parniske, M. 2002. A plant receptor-like kinase required for both bacterial and fungal symbiosis. Nature 417:959-962

Synek, L., Schlager, N., Elias, M., Quentin, M., Hauser, M. T., and Zarsky, V. 2006. AtEXO70A1, a member of a family of putative exocyst subunits specifically expanded in land plants, is important for polar growth and plant development. Plant J. 48:54-72.

Tadege, M., Wen, J., He, J., Tu, H., Kwak, Y., Eschstruth, A., Cayrel, A., Endre, G., Zhao, P. X., Chabaud, M., Ratet, P., and Mysore, K. S. 2008. Large-scale insertional mutagenesis using the Tnt1 retrotransposon in the model legume Medicago truncatula. Plant J. 54:335-347.

Tanimoto, M., Roberts, K., and Dolan, L. 1995. Ethylene is a positive regulator of root hair development in Arabidopsis thaliana. Plant $\mathrm{J}$. 8:943-948.

Tansengco, M. L., Hayashi, M., Kawaguchi, M., Imaizumi-Anraku, H., and Murooka, Y. 2003. crinkle, a novel symbiotic mutant that affects the infection thread growth and alters the root hair, trichome, and seed development in Lotus japonicus. Plant Physiol. 131:1054-1063.

Tansengco, M. L., Imaizumi-Anraku, H., Yoshikawa, M., Takagi, S., Kawaguchi, M., Hayashi, M., and Murooka, Y. 2004. Pollen development and tube growth are affected in the symbiotic mutant of Lotus japonicus, crinkle. Plant Cell Physiol. 45:511-520.

Till, B. J., Reynolds, S. H., Greene, E. A., Codomo, C. A., Enns, L. C., Johnson, J. E., Burtner, C., Odden, A. R., Young, K., Taylor, N. E. Henikoff, J. G., Comai, L., and Henikoff, S. 2003. Large-scale discov- 
ery of induced point mutations with high-throughput TILLING. Genome Res. 3:524-530.

Timmers, A. C., Auriac, M. C., and Truchet, G. 1999. Refined analysis of early symbiotic steps of the Rhizobium-Medicago interaction in relationship with microtubular cytoskeleton rearrangements. Development 126:3617-3628

Tirichine, L., Sandal, N., Madsen, L. H., Radutoiu, S., Albrektsen, A. S., Sato, S., Asamizu, E., Tabata, S., and Stougaard, J. 2007. A gain-of-function mutation in a cytokinin receptor triggers spontaneous root nodule organogenesis. Science 315:104-107.

van Brussel, A. A., Bakhuizen, R., van Spronsen, P. C., Spaink, H. P., Tak, T., Lugtenberg, B. J., and Kijne, J. W. 1992. Induction of pre-infection thread structures in the leguminous host plant by mitogenic lipo-oligosaccharides of Rhizobium. Science 257:70-72.

Vandenbosch, K. A., Bradley, D. J., Knox, J. P., Perotto, S., Butcher, G. W., and Brewin, N. J. 1989. Common components of the infection thread matrix and the intercellular space identified by immunocytochemical analysis of pea nodules and uninfected roots. EMBO (Eur. Mol. Biol. Organ.) J. 8:335-341.

van Spronsen, P. C., Bakhuizen, R., van Brussel, A. A., and Kijne, J. W. 1994. Cell wall degradation during infection thread formation by the root nodule bacterium Rhizobium leguminosarum is a two-step process. Eur. J. Cell Biol. 64:88-94.

van Spronsen P. C., van Brussel A. A., and Kijne J. W. 1995. Nod factors produced by Rhizobium leguminosarum biovar viciae induce ethylenerelated changes in root cortical cells of Vicia sativa ssp. nigra. Eur. J. Cell Biol. 68:463-469.

Vassileva, V. N., Kouchi, H., and Ridge, R. W. 2005. Microtubule dynamics in living root hairs: transient slowing by lipochitin oligosaccharide nodulation signals. Plant Cell 17:1777-1787.

Wais, R. J., Galera, C., Oldroyd, G., Catoira, R., Penmetsa, R. V., Cook, D., Gough, C., Denarie, J., and Long, S. R. 2000. Genetic analysis of calcium spiking responses in nodulation mutants of Medicago truncatula. Proc. Natl. Acad. Sci. U.S.A. 97:13407-13412.

Ward, H. M. 1887. On the tubercular swellings on the roots of Vicia faba. Philos. Trans. R. Soc. London Ser. B 178:539-562.

Weerasinghe, R. R., Collings, D. A., Johannes, E., and Allen, N. S. 2003.
The distributional changes and role of microtubules in Nod factor-challenged Medicago sativa root hairs. Planta 218:276-287.

Weerasinghe, R. R., Bird, D. M., and Allen, N. S. 2005. Root-knot nematodes and bacterial Nod factors elicit common signal transduction events in Lotus japonicus. Proc. Natl. Acad. Sci. U.S.A. 102:3147-3152.

Yang, W. C., Deblank, C., Meskiene, I., Hirt, H., Bakker, J., Vankammen, A., Franssen, H., and Bisseling, T. 1994. Rhizobium Nod factors reactivate the cell-cycle during infection and nodule primordium formation, but the cycle is only completed in primordium formation. Plant Cell 6:1415-1426.

Yang, Z. B. 2002. Small GTPases: versatile signaling switches in plants. Plant Cell 14:S375-S388.

Yano, K., Tansengco, M. L., Hio, T., Higashi, K., Murooka, Y., ImaizumiAnraku, H., Kawaguchi, M., and Hayashi, M. 2006. New nodulation mutants responsible for infection thread development in Lotus japonicus. Mol. Plant-Microbe Interact. 19:801-810.

Yano, K., Yoshida, S., Muller, J., Singh, S., Banba, M., Vickers, K., Markmann, K., White, C., Schuller, B., Sato, S., Asamizu, E., Tabata, S., Murooka, Y., Perry, J., Wang, T. L., Kawaguchi, M., ImaizumiAnraku, H., Hayashi, M., and Parniske, M. 2008. CYCLOPS, a mediator of symbiotic intracellular accommodation. Proc. Natl. Acad. Sci. U.S.A. 105:20540-20545.

Yano, K., Shibata, S., Chen, W. L., Sato, S., Kaneko, T., Jurkiewicz, A. Sandal, N., Banba, M., Imaizumi-Anraku, H., Kojima, T., Ohtomo, R., Szczyglowski, K., Stougaard, J., Tabata, S., Hayashi, M., Kouchi, H., and Umehara, Y. 2009. CERBERUS, a novel U-box protein containing WD-40 repeats, is required for formation of the infection thread and nodule development in the legume-Rhizobium symbiosis. Plant J. 60:168-180.

Yokota, K., Fukai, E., Madsen, L. H., Jurkiewicz, A., Rueda, P., Radutoiu, S., Held, M., Hossain, M. S., Szczyglowski, K., Morieri, G., Oldroyd, G. E., Downie, J. A., Nielsen, M. W., Rusek, A. M., Sato, S., Tabata, S., James, E. K., Oyaizu, H., Sandal, N., and Stougaard, J. 2009. Rearrangement of actin cytoskeleton mediates invasion of Lotus japonicus roots by Mesorhizobium loti. Plant Cell 21:267-284.

Zhang, Y., Liu C. M., Emons, A. M., and Ketelaar, T. 2010. The plant exocyst. J. Integr. Plant Biol. 52:138-146. 